Supplementary information

\title{
Unexplained hydrogen isotope offsets complicate the identification and quantification of tree water sources in a riparian forest
}

Adrià Barbeta ${ }^{1}$, Sam Jones ${ }^{1}$, Laura Clavé ${ }^{1}$, Lisa Wingate $^{1}$, Teresa E. Gimeno ${ }^{1,2,3}$, Bastien Fréjaville $^{1}$, Steve Wohl ${ }^{1}$, Jérôme Ogée ${ }^{1}$

${ }^{1}$ INRA, UMR ISPA, F-33140, Villenave d'Ornon, France

${ }^{2}$ BC3 - Basque Centre for Climate Change - Klima Aldaketa Ikergai, E-48940, Leioa, Spain

${ }^{3}$ IKERBASQUE, Basque Foundation for Science, 48008 Bilbao, Spain

Correspondence to: Adrià Barbeta (adria.barbeta.margarit@gmail.com)

Table S1: Soil properties of the three differentiated horizons in the studied plots. Values are obtained from pooled samples from all the sites where soil was sampled for stable isotopes.

\begin{tabular}{|c|c|c|c|c|c|c|c|c|c|c|}
\hline Horizon & $\begin{array}{l}\text { Depth } \\
(\mathrm{cm})\end{array}$ & $\begin{array}{l}\text { Clay } \\
\left(\mathrm{g} \cdot \mathrm{kg}^{-1}\right)\end{array}$ & $\begin{array}{l}\text { Fine silt } \\
\text { (g.kg-1) }\end{array}$ & $\begin{array}{l}\text { Coarse silt } \\
(\mathrm{g} . \mathrm{kg}-1)\end{array}$ & $\begin{array}{l}\text { Fine sand } \\
\text { (g.kg-1) }\end{array}$ & $\begin{array}{l}\text { Coarse sand } \\
(\mathrm{g} . \mathrm{kg}-1)\end{array}$ & $\begin{array}{l}\text { Carbon } \\
(\mathrm{g} . \mathrm{kg}-1)\end{array}$ & $\begin{array}{l}\text { Nitrogen } \\
\text { (g.kg-1) }\end{array}$ & $\begin{array}{l}\mathrm{CaCO} 3 \\
\text { (g.kg-1) } \\
\end{array}$ & $\mathrm{pH}$ \\
\hline A & $0-10$ & 44 & 16 & 9 & 106 & 825 & 17.3 & 0.52 & 75 & 8.05 \\
\hline $\mathrm{B}$ & $10-50$ & 37 & 24 & 6 & 115 & 818 & 19.4 & 0.792 & 37 & 7.93 \\
\hline $\mathrm{C}$ & $50-120$ & 81 & 93 & 39 & 455 & 332 & 52.2 & 0.467 & 388 & 8.24 \\
\hline
\end{tabular}

Table S2: Output of the generalized linear model for the SW-excess $x$ and its explanatory variables. The $\beta$ coefficient is the standardized correlation coefficient for each of the independent variables. Statistically significant variables are highlighted with one $(P<0.05)$ or two asterisks $(P<0.01)$. The marginal $R^{2}$ was $16 \%$.

\begin{tabular}{|l|r|r|r|r|r|r|}
\hline Variable & Estimate & $\beta$ coefficient & \multicolumn{1}{|c|}{ Std. Error } & \multicolumn{1}{l}{$\begin{array}{l}\text { legrees of } \\
\text { freedom }\end{array}$} & $t$-value & $P$-value \\
\hline (Intercept) & -7.54 & & 4.72 & 76.23 & -1.60 & 0.114 \\
\hline $\begin{array}{l}\text { Top soil water } \\
\text { content (log) }\end{array}$ & 3.31 & 0.37 & 0.80 & 9.90 & 4.16 & 0.002 \\
\hline $\begin{array}{l}\text { Deep soil water } \\
\text { content (log) }\end{array}$ & 1.38 & 0.11 & 1.20 & 123.86 & 1.15 & 0.254 \\
\hline Deep soil $\delta^{18} \mathrm{O}$ & -2.40 & -0.24 & 0.94 & 154.48 & -2.54 & 0.012 \\
\hline Rock $\delta^{18} \mathrm{O}$ & 1.54 & 0.22 & 0.53 & 61.55 & 2.89 & 0.005 \\
\hline VPD & 3.36 & 0.15 & 2.08 & 4.49 & 1.61 & 0.174 \\
\hline $\begin{array}{l}\text { Species }(Q . \\
\text { robur) }\end{array}$ & 1.47 & 0.12 & 0.83 & 166.99 & 1.76 & 0.080 \\
\hline
\end{tabular}



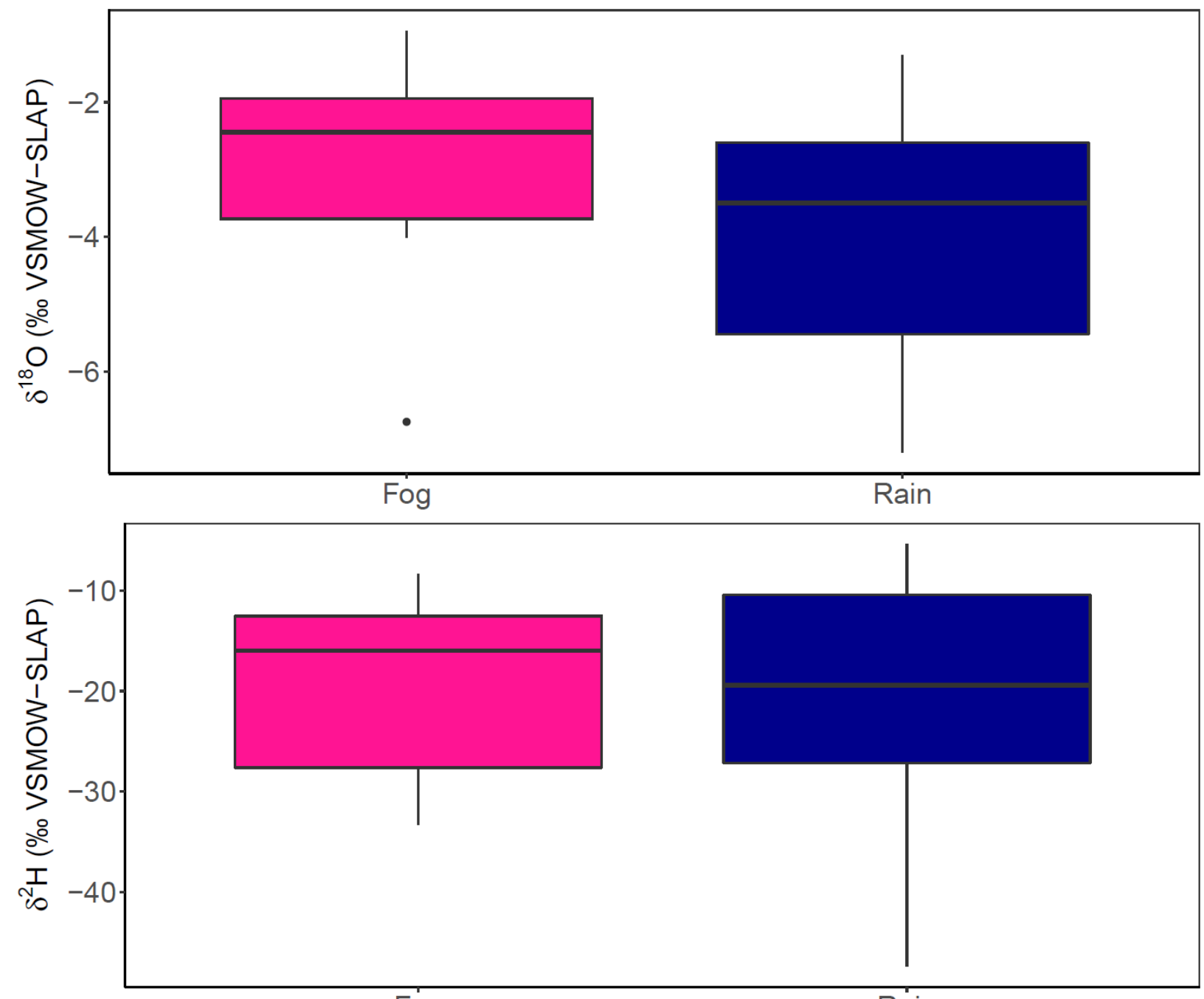

Fog

Rain

Figure S1: Comparison of water stable isotopes of fog and rain for the samples collected in 2017 in the Ciron. Box size represents the interquartile range, the black line is the median, the whiskers indicate variability outside the upper and lower quartiles, and individual points are outliers. 


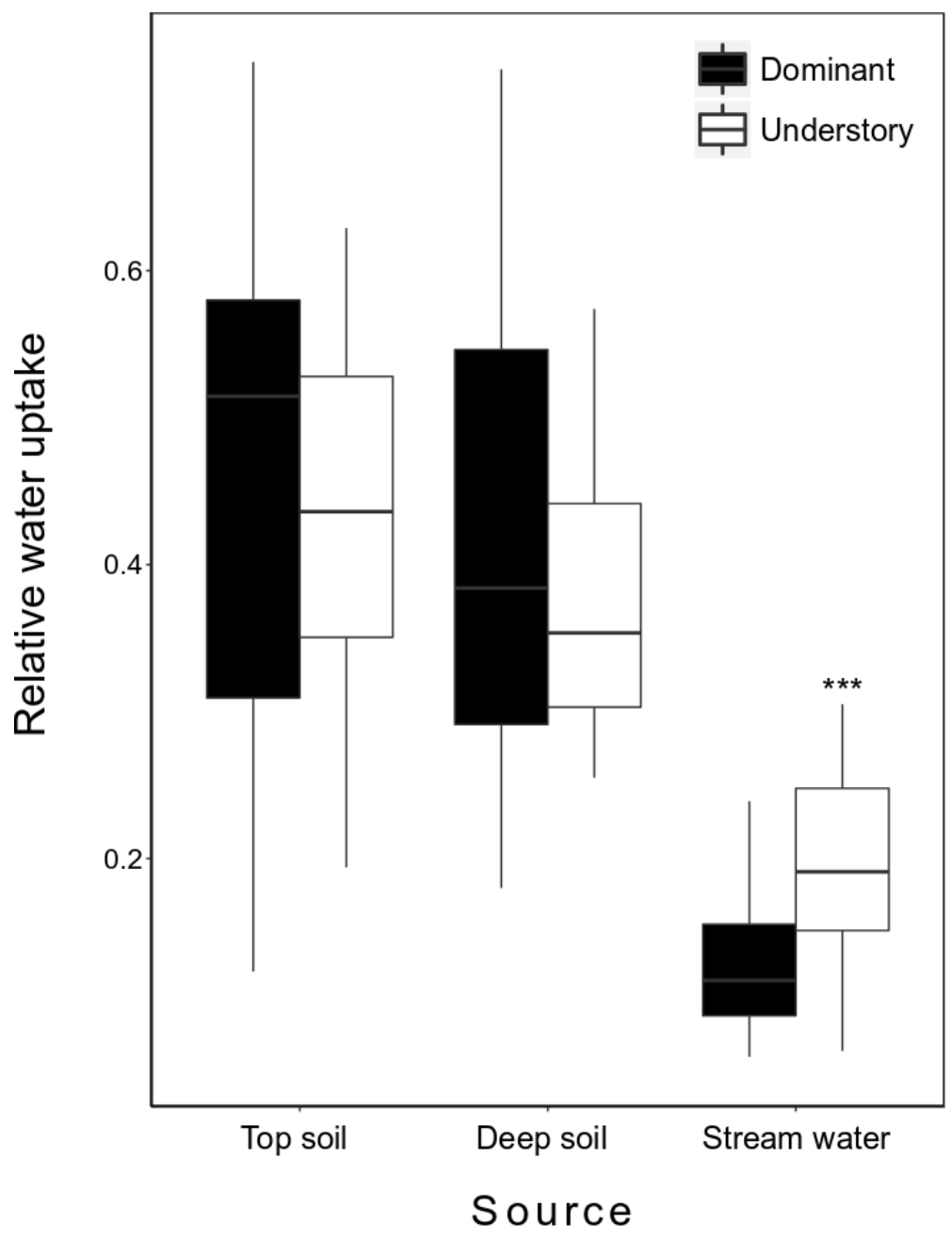

Figure S2: Comparison between the proportion of each plant-water source of dominant and understory. Box size represents the interquartile range, the black line is the median, the whiskers indicate variability outside the upper and lower quartiles, and individual points are outliers. Significant differences between canopy positions are highlighted with $* * *(P<0.001)$. 